\title{
'Remembrances of a Distant Past': Generational Memory and the Collective Auto/Biography of Russian Populists in the Revolutionary Era
}

\author{
BEN EKLOF and TATIANA SABUROVA
}

\begin{abstract}
'We are linked inseparably by the irretrievable past.' Egor Lazarev to Fanni Kravchinskaia, 29 October 1932
\end{abstract}

Recent studies of Russian Populism, many of which are biographical in approach, have focused almost exclusively upon its engagement with terrorism. ${ }^{2}$ In reality, while the terrorist People's Will did emerge out of the Populist movement, that organization was in fact a radical departure from the deeply-held beliefs of its founders, one driven by frustration rather than by temperament or core doctrine. The larger movement had its origins in the Chaikovskii Circle in the 1870s: a group of young men

Ben Eklof is Professor of History at Indiana University, and Tatiana Saburova is a Research Fellow at the Higher School of Economics in Moscow and Visiting Professor at the University of Alberta.

Tatiana Saburova carried out research for this article as part of the Basic Research Program at the National Research University Higher School of Economics (HSE), which is supported by a subsidy from the Government of the Russian Federation for the implementation of the Global Competitiveness Program. Ben Eklof received a grant from the College Arts and Humanities Institute at Indiana University.

1 Columbia University, Rare Book and Manuscript Library, Bakhmeteff Archive, the Sergei Mikhailovich Kravchinskii Papers, Box 1. (By 'we' Lazarev is referring to Ekaterina Breshko-Breshkovskaia.)

${ }^{2}$ Much recent work concentrates primarily on the links between Populism and either terror or religion. See Susan K. Morrissey, 'Terrorism, Modernity, and the Question of Origins', Kritika: Explorations in Russian and Eurasian History, 12, Winter 2011, 1, pp. 215-26, and Claudia Verhoeven, The Odd Man Karakozov: Imperial Russia, Modernity and the Birth of Terrorism, Ithaca, NY, 2009. 
and women who, in reaction to the infamous Nechaev scandal, ${ }^{3}$ set out to establish a movement based upon high ethical standards, group solidarity and a dedication to serving the people by bringing about a social and political transformation of Russian life. Populism (the name came later at the time this generation called themselves 'propagandists' or socialist revolutionaries) evolved into a huge, diversified and somewhat amorphous political constellation, one which (especially in its neo-Populist variant) espoused radical goals, but sought a pathway to these ends through gradualist means. ${ }^{4}$ It developed a sophisticated and detailed programme of societal and political transformation, as well as economic theories (especially that of the Chaianov school), which later in the twentieth century caught the attention of global developmental economists. In 1917, Populists occupied prominent positions in the Provisional Government, both in Petrograd and in the provinces, but of course ultimately their cause lost out to the Bolsheviks, who offered, as William Rosenberg has pointed out, 'a capacity for organization, an ideological clarity, and a social positioning that facilitated affiliation with the radical relocation of power and authority.'.

In this article, we describe the construction of a collective remembrance by 'losers' in the events of 1917 and the subsequent Civil War; a concerted writing project which unfolded during the first decade or so of Soviet rule. In short, below we apply the tools of memory ${ }^{6}$ and generational

\footnotetext{
3 Nechaev was an unscrupulous but charismatic Populist affiliated with Bakunin, author of 'The Catechism of a Revolutionary', in which youth were encouraged to reject all conventional moral values in the cause of the revolution. He convinced a small group that he was connected with a vast conspiratorial organization abroad; when one student became suspicious of these false claims, Nechaev had him murdered. The episode was the subject of Dostoevskii's novel, Besy (The Possessed).

4 There is an enormous literature on Russian Populism. Foundational works include Franco Venturi, Roots of Revolution: A History of the Populist and Socialist Movements in Nineteenth Century Russia, New York, 1966; Boris Itenberg, Dvizhenie revoliutsionnogo narodnichestva, Moscow, 1965; Nikolai Troitskii, Pervye iz blestiaschei pleiady: Bol'shoe obshchestvo propagandy 1871-1874, Saratov, 1991. For the wave of interest in Populism in the 196os and ' 70 , see Philip Pomper, The Russian Revolutionary Intelligentsia, 2nd edn, Wheeling, IL, 1993, and especially on the Chaikovskii Circle: Reginald Zelnik, 'Populists and Workers: The First Encounter between Populist Students and Industrial Workers in St. Petersburg, 1871-1874', Soviet Studies, 24, October 1972, 2, pp. 251-69, and Martin A. Miller, 'Ideological Conflicts in Russian Populism: The Revolutionary Manifestoes of the Chaikovsky Circle', 1869-1875, Slavic Review, 29, March 1970, 1, pp. 1-21.

5 Edward Acton, V. I. Cherniaev, and William G Rosenberg, Critical Companion to the Russian Revolution 1914-1921, Bloomington, IN, 1997, pp. 29-30.

6 On the approaches of memory studies, see the recent article by Gregor Feindt, Félix Krawatzek, Daniela Mehler, Friedemann Pestel and Rieke Trimçev, 'Entangled Memory: Toward a Third Wave in Memory Studies', History and Theory, 53, February 2014, pp.
} 
studies $^{7}$ to show how networks of exiles in the imperial period came together in the Soviet era to defend and preserve the legacy of their movement through a collective project of autobiographical writing in which the genres of memoir, biography and autobiography merged, and individual voices combined. Specifically, we follow the stages by which one 'Old Revolutionary' (as members of this generation insisted on labelling themselves) Nikolai Charushin (1851-1937), turned reluctantly to writing his memoirs, $O$ dalekom proshlom (Remembrances of a Distant Past), published in three volumes. First published in 1926, the volume was positively received. A second volume, O dalekom proshlom. Na Kare (Remembrances of a Distant Past: Kara), went through a tortuous route and was published in 1929 only with a critical introduction by (the prominent figure in early Soviet ideological affairs and fellow former exile) Felix Kon. The third segment, $\mathrm{O}$ dalekom proshlom. $\mathrm{Na}$ poselenii (Remembrances of a Distant Past: Penal) was delayed and published in a limited print run in $1931 .^{8}$ For our purposes, most revealing was the process by which the memoirs culminated in a collaborative effort by the 1870 os generation of Populists to inscribe, preserve and defend their memory.

Others more prominent, especially the venerable 'icon of the revolution', Vera Figner (1852-1942), appear on these pages as significant contributors to this project. As for Charushin, despite having played an important role in the early Populist movement, his is hardly a household name even among historians of modern Russia. ${ }^{9}$ Yet his memoirs appear frequently in

24-44. About the theoretical foundations and basic concepts, see Aleida Assmann, and Sarah Clift, Shadows of Trauma: Memory and the Politics of Postwar Identity, New York, 2016, and specifically, Astrid Erll, 'Travelling Memory: Whither Memory Studies', Parallax, 17, 2011, pp. 4-18.

7 Karl Mannheim, 'The Problem of Generations', in Karl Mannheim, Essays on the Sociology of Knowledge, London, 1952 (1923); Howard Schuman, Jacqueline Scott, 'Generations and Collective Memories', The American Sociological Review, 54, 1989, pp. 359-81; Alan B. Spitzer, 'The Historical Problem of Generations', The American Historical Review, 78, 1973, pp. 1353-85 (see also his book, The French Generation of 1820, Princeton, NJ, 1987); Harald Wydra, 'Dynamics of Generational Memory: Understanding the East and West Divide', in Eric Langenbacher, Bill Niven, and Ruth Wittlinger (eds), Dynamics of Memory and Identity in Contemporary Europe, New York, 2012.

8 O dalekom proshlom, Moscow, 1926. A second edition was published in 1973 with annotations by Boris Itenberg; all references below are from the second edition. O dalekom proshlom. Na Kare, Moscow, 1929; O dalekom proshlom. Na poselenii, Moscow, 1931.

9 See Tatiana Saburova and Ben Eklof, Druzhba, sem' ia, revoliutsiia: Nikolai Charushin i pokolenie narodnikov 1870-ikh godov v Rossii, Moscow, 2016; Ben Eklof and Tatiana Saburova, A Generation of Revolutionaries: Nikolai Charushin and Russian Populism from the Great Reforms to Perestroika, Bloomington, IN, 2017. A brief autobiographical sketch of his life can be found in Deiateli SSSR i revoliutsionnogo dvizheniia Rossii. Entsiklopedicheskii slovar' Granat, Moscow, 1989, pp. 539-63. See also, V. D. Sergeev, 
histories of the Russian revolutionary movement. ${ }^{10}$ For that reason - the relative obscurity of the person and the prominence of the memoirs - we believe an examination of how they came into being forms a promising platform for studying the intersection of self (life)-writing, collective auto/ biography, generational identity and social memory in modern Russia.

Below we analyse how the individualized effort at memoir writing became a process of consolidating social memory, resulting in an 'entangled' or 'travelling' narrative and, in effect, an autobiographical account which at the same time served to tell the life stories of Charushin's comrades of the 1870 generation - a collective auto/biography. In this account Charushin himself sometimes fades into the background; at many points in $O$ dalekom proshlom in fact, the voice of the author of the text becomes problematic, so that memoir, autobiography and biography become scrambled. Writing in exile from Viatka in 1929, the anarchist and philosopher Aleksei Borovoi caught the essence both of Charushin's personality and the task that person had set for himself in writing his memoirs, which Borovoi had just completed reading. While praising the parsimony of language, the unadorned style of the narrative and the person of the author himself which emerges from the pages of $O$ dalekom proshlom, Borovoi hits upon the collective nature of the Populist memory project in his assertion that the author 'always and in every way left himself in the shadows. ${ }^{11}$

\section{Social Memory and Generational Identity}

Much has already been written about the Soviet state's efforts to mobilize and manipulate social memory through the device of commemorations, museums, memoirs - the lieux de mémoire (sites of memory) classically described in a different context by Pierre Nora. ${ }^{12}$ In particular, the work of Frederic Corney deftly examines how Party institutions worked hard to create and polish an official narrative describing the October revolution

Nikolai Apollonovich Charushin: narodnik, obshchestvennyi deiatel', izdatel', kraeved, Kirov, 2001.

${ }^{10}$ In his monumental history of the Populist movement Franco Venturi refers often to Charushin's memoirs, but concludes that Sinegub's were even more valuable for the historian. Venturi, Roots of Revolution, p. 474. For a more recent work utilizing his narrative, see E. I. Shcherbakova, Otshetpentsy: Put' k terrorizmu (6o-8o-gody XIX veka), Moscow, 2008, pp. 83-152.

${ }^{11}$ Russian State Archive of Literature and Art (hereafter, RGALI), f. 1023, op. 1, d. 173, 1. 85.

${ }^{12}$ Pierre Nora, 'Between Memory and History: Les Lieux de Mémoire', Representations, 26, Spring 1989, pp. 7-24. 
of 1917 as a seminal event in history - something seemingly evident in retrospect but needing to be established at the time. ${ }^{13}$ Sandra Pujals and Marc Junge have both produced studies of the Society of Former Political Prisoners and Exiles (OPK) founded in 1921, which became a pivotal battleground in the 'memory wars' between the Bolsheviks and remnants of other leftist parties. ${ }^{14}$ These struggles culminated in 1935 with the dismantling of this organization, the banning of all discussion of Populism and the arrest of many of its surviving members.

The terminology employed in memory studies remains a work in progress. ${ }^{15}$ To use the terms of one of the founders of memory studies, Maurice Halbwachs, collective memory is shaped only within and by a distinctive 'social frame'. However, some scholars have challenged the very existence of collective memory, arguing instead that only individual memory endures, or that memory shapes social identity itself. Aleida Assmann seeks to bridge these differences by arguing that all individual remembrances do in fact have a societal component, since they are constructed within a web of societal engagement and are always connected with the recollections of others. But, she continues, as long as such multiple recollections remain unintegrated into a common narrative both situating and simultaneously providing them with meaning, they remain fragmentary and disconnected, subject to alteration or even loss. ${ }^{16}$ Thus, 'social memory' (the term she prefers to collective memory) emerges from a conscious and collaborative effort to shape a distinct narrative.

One such variant of social memory is generational memory, which is especially stable, and also shaped by the social frame. As Assmann notes: 'generational memory is an important element in the constitution of personal memories, because [...] once formed, generational identity cannot change.' ${ }^{17}$ In Assmann's lexicon, generational memory is distinct from

${ }^{13}$ Frederick C. Corney, Telling October: Memory and the Making of the Bolshevik Revolution, Ithaca, NY, 2004.

${ }^{14}$ Marc Junge, Revoliutsionery na pensii: Vsesoiuznoe Obshchestvo Politkatorzhan i Ssyl'noposelentsev, 1921-1935, Moscow, 2015; Sandra Pujals, 'When Giants Walked the Earth: The Society of Former Political Prisoners and Exiles of the Soviet Union, 1921-1935', unpublished $\mathrm{PhD}$ dissertation, Georgetown University, 1999.

${ }^{15}$ On memory studies, see Jeffrey K. Olick and Joyce Robbins, 'Social Memory Studies: From "Collective Memory" to the Historical Sociology of Mnemonic Practices', Annual Review of Sociology, 24, 1998, pp. 105-40.

${ }^{16}$ Aleida Assmann, 'Re-framing Memory: Between Individual and Collective Forms of Constructing the Past', in Tilmans, Karin, Frank van Vree and J. M Winter (eds), Performing the Past: Memory, History, and Identity in Modern Europe, Amsterdam, 2010, pp. 35-50 (pp. 40-41).

17 Ibid., p. 41. 
both political and cultural memory, both of which have trans-generational potential. In this essay, we adhere to her conceptualization.

We see then that in the theoretical literature discussions of social memory often overlap with attempts to conceptualize identity (or 'selfidentification' as a process). ${ }^{18}$ Stephen Lovell has aptly shown how, in the multi-layered society that was imperial Russia, generational 'thinking' was a crucial means of self-identification. ${ }^{19}$ As for generation, we understand the term as Karl Mannheim used it - namely as an age cohort sharing a common societal experience - but also in the terms Pierre Nora used: as a specific 'site of memory'. One is a sociological frame, the other a discursive construct. Thus, the 'seventies generation' we describe was a self-selective group drawn from the larger age cohort, many of whom - including often siblings - though sitting on the same school benches became civil servants, military officers, or prominent entrepreneurs rather than revolutionaries. ${ }^{20}$ Below we trace how a group thinking in generational terms ('the seventies generation') evolved from the early twentieth century into the Soviet era when 'old revolutionaries' were forced to defend themselves and the legacy of Populism against an increasingly hostile state, and sought to create a larger, historical memory.

\section{Charushin: A Short Biography}

Nikolai Charushin grew up in provincial Viatka, five hundred miles northeast of Moscow. Like many others of his generation, upon completion of his studies at a local gymnasium he enrolled in the Technological Institute at St Petersburg, but soon dropped out to join the small circle of young men and women, including more notable figures such as Nikolai Chaikovskii, Sofia Perovskaia and Petr Kropotkin, which sought to spread its influence among students and the intelligentsia, and then to reach out to the peasantry by recruiting factory workers with ties to the countryside. This Chaikovskii Circle was soon penetrated by the police and most of its members arrested. Charushin himself spent nearly four years mostly in solitary confinement before being tried and convicted in 1878 in the sensational 'Trial of the 193'. Sentenced to hard labour and exile, Charushin and his wife, Anna Kuvshinskaia, also a dedicated Populist,

\footnotetext{
${ }^{18}$ Rogers Brubaker and Frederick Cooper, 'Beyond "Identity"', Theory and Society, 29, 2000, 1 , pp. $1-47$.

19 Stephen Lovell, 'From Genealogy to Generation: The Birth of Cohort Thinking in Russia', Kritika: Explorations in Russian and Eurasian History, 9, 2008, 3, pp. 567-94.

${ }^{20}$ Alfred J. Rieber, 'The Sedimentary Society', in E. W. Clowes (ed.), Between Tsar and People: Educated Society and the Quest for Public Identify in Late Imperial Russia, Princeton, NJ, 1991, p. 351.
} 
spent the next seventeen years in Siberian exile; first in Kara, then in Nerchinsk, and finally in Kiakhta-Troitskosavsk, the tea entrepôt on the border with China. In this period of exile, the Charushins interacted with many prominent fellow populists, such as Ivan Popov, Dmitrii Klements, Felix Volkhovskii, Leonid Shishko and Sergei Sinegub, but also established a lasting friendship with the commandant of the Kara penal system, Vladimir Kononovich; befriended prominent figures such as the Kiakhta tea merchant and public philanthropist A. M. Lushnikov and worked and travelled about Mongolia with the renowned explorer Grigorii Potanin. In exile, Charushin became a professional photographer, whose works were collected by the Russian Geographic Society, and have gained entry into histories of Russian photography. Upon returning in 1895 to his native Viatka, Charushin soon was engaged by the zemstvo, which he served for twelve years before being purged in the aftermath of the 1905 Revolution. In late 1905 he founded a newspaper, Viatskaia Zhizn' (later renamed Viatskaia Rech', 1907-17), which soon gained national recognition and was labelled by Prime Minister Stolypin 'the most radical provincial newspaper in Russia'. In these years, he was active in the Peasant Union and the People's Socialist (NS) Party.

With the arrival of the Provisional Government in 1917, Charushin renewed his civic activities on several fronts. He served in the reborn Peasant Union as well as on the Central Committee of the NS Party, now renamed the Trudovaia Narodno-Sotsialisticheskaia Partiia, which played a significant role in the Provisional Government. He was again active in zemstvo affairs and served on the crucial food provision committee. ${ }^{21}$

With the Bolshevik seizure of power in October in Petrograd, Charushin gave a passionate speech to an extraordinary session of the zemstvo assembly, in which he lamented that:

Fellow citizens and delegates, that which we feared and awaited apprehensively, has happened - in Petrograd a civil war has begun. A host of new calamities has now been added to general internal collapse at the front and in the rear lines. I believe that we, and not only the old regime, are to blame for the current situation. We worked relentlessly to deepen the revolution, and in the end deepened it to the point of Bolshevism. ${ }^{22}$

${ }^{21}$ A full listing of his affiliations can be found in a biographical entry in Trudovaia Narodno-Sotsialisticheskaia Partiia: Dokumenty i materialy, Moscow, 2003, pp. 583-84.

${ }^{22}$ Gosudarstvennyi Arkhiv Kirovskoi Oblasti (hereafter, GAKO), f. 616, op. 1, d. 267, 1. 66; Viatskaia rech', 28 October 1917, p. 3. 
He was elected to serve on a Supreme Council formed by the provincial zemstvo assembly, which proclaimed Viatka an independent republic and sought to organize resistance to the Bolsheviks. Charushin was arrested in late December, came before a revolutionary tribunal in January 1918, was released because of his 'irreproachable past service to the revolution', but incarcerated three more times during the subsequent civil war. Undeterred, he wrote to the Revolutionary Tribunal judging his case a bitter note:

At the very time that the new Soviet regime is memorializing those who gave their lives in the cause of freedom, paying them every manner of tribute - plans are underway to build monuments to [Sofia] Perovskaia, [Andrei] Zheliabov and others of my comrades in the revolutionary struggle - at the same time, I repeat, those among their comrades who survive today and can boast of an 'irreproachable political past' which one would think this regime would also respect, can find no place in the Soviet Socialist Republic other than in prison! ${ }^{23}$

These words foreshadowed the situation he would face in the following decade as he was writing his memoirs: a complex official martyrology in which the sacrifices of earlier Populists were commemorated at the same time that survivors of that cohort were being marginalized or worse in the new Soviet reality. When released for good in 1919 at the age of sixty-seven, it was on the condition he stay out of politics. Charushin, unlike some of his friends, chose to remain in the country seeking meaningful activity in what was becoming an increasingly constraining political environment. He worked briefly in the cooperative movement, and then, between 1921 and 1930 was employed at the Herzen Regional Library in Viatka. From 1922 he was a member of the OPK, a year after its founding. Resigning from the library in 1930 in despair over the ripples of the Cultural Revolution there, he lived a solitary and hungry last few years, before dying a natural death at the age of eighty-five in 1937.

Charushin's life was certainly a tragic one. Arrest and exile, physical hardship, personal loss, and having to witness the social and political transformation he had worked for all his life going so terribly awry in the years after the Revolution left its imprint on him. But it was also a rich and meaningful life, in both private and public terms. In fact, Charushin's

${ }^{23}$ Gosudarstvennyi Arkhiv Sotsial'no-Politicheskoi Istorii Kirovskoi Oblasti, f. SU 6799 , op. 4 , d. 4577, l. 22-23 ob. The reference to 'irreproachable service' is a reference to the conclusions of the Revolutionary Tribunal's conclusions following his first arrest and trial by the Bolsheviks in January 1918. 
engagement with civil society after returning from exile in 1895, his work for the zemstvo as a fire insurance and famine relief agent, his years with Viatskaia Rech', his affiliation with liberal democratic and neo-Populist political organizations, and even with prominent local entrepreneurs in the world of business, might lead us to question his revolutionary credentials later in life.

However, as he aged he never wavered from his self-description as 'an old revolutionary' who, along with his friends, had given their best years of their life to the cause of socialism. The friendships which had coalesced in Viatka circles during his student years and the bonds of the Chaikovskii Circle remained tight to the end of his life. He participated in a large and diverse network of fellow former exiles circulating between Kazan', Nizhnii Novgorod, Viatka, Perm', St Petersburg and Moscow, and pursuing life trajectories similar to his. It is no wonder that in his later years when, determined to protect and memorialize the meaningful legacy of his own life, he sought to include his peers and comrades, both in the writing and in the text itself of his memoirs. To that production of a hybrid genre of life writing in the 1920 se now turn.

\section{Inscribing the Populist Legacy}

In the 1920 s there was both official and societal demand for memoirs dealing with the revolutionary movement. At this time in Soviet Russia, official prominence was given to recollections of tsarist prisons, hard labour and exile, creating a narrative of martyrdom or heroism, articulated through repression and 'suffering'. Those who experienced incarceration under the tsarist regime genuinely underwent much hardship, and some had not been able to endure the sufferings and indignities heaped upon them; they went insane, or even committed suicide when the accumulated physical and moral trauma proved to be too much. But as we see below, suffering - a trope much repeated by Western historians in their analysis of the memoirs forthcoming in this generation, was by no means the only motif emphasized. ${ }^{24}$

Scholars have accordingly labelled the decade after the Revolution one of an 'explosion' of memoirs; an outpouring generated both by Soviet policies and by the activities of the OPK. The notion of a 'memoir explosion' is supported by the abundance of publications of that society, many of which

${ }^{24}$ The trope of suffering, in terms both of experience and of self-presentation, is central to the biography of Figner written by Lynne A. Hartnett, The Defiant Life of Vera Figner: Surviving the Russian Revolution, Bloomington, IN, 2014. See Tatiana Saburova's review of this book in The American Historical Review, 120, 2015, 1, pp. 357-58. 
were issued by its house journal, Katorga i Ssylka (Hard Labour and Exile). The majority of such memoirs received positive reviews in the 1920s; their educational value was emphasized by Dmitrii Furmanov, the popular Soviet author and former political commissar (author of Chapaev), who wrote 'the will to struggle is reinforced by such vibrant and convincing material'. ${ }^{25}$ The most illustrious example of such memoir literature was the work of Vera Figner, The Imprint of Life's Endeavours (Zapechatlennyi trud). Bringing up the next generation on tales of the heroic exploits of opposition to autocracy, of sacrificing one's personal interests and needs on the altar of the common good and dedication, of one's life to the cause of revolution - all of this was called for and met a positive response in society, as is demonstrated by the abundance of letters addressed to Figner personally after publication of these memoirs. Here we have an obvious case where individual, societal and political memories are inseparable since, as Assmann points out, 'political memory is not fragmentary and diverse but emplotted in a narrative that is emotionally charged, and conveying a clear and invigorating message.. ${ }^{26}$ Assmann further argues that political memory, reinforced by a plethora of visual, material objects as well as commemorative practices, achieves a definitive stability and (unlike generational memory) can be passed from generation to generation.

Figner was also instrumental in recruiting a series of autobiographical essays for publication by Granat in 1926. The more than forty autobiographical essays collected for that oft-utilized volume were written at her request, and after she had sent out guidelines asking them to answer the question 'why they had become revolutionaries'. ${ }^{27}$ As Hilda Hoogenboom has shown, Figner energetically corresponded with the participants to help them shape their narratives, emphasizing the need to search for formative emotional experiences or readings in their childhood. Some of the published autobiographies in the Granat volume include Figner's annotations. ${ }^{28}$

${ }^{25}$ Pechat' i revoliutsiia. 1, 1926, p. 189.

${ }^{26}$ Assmann, 'Re-framing memory', p. 43.

27 The line originated in a notorious open letter, 'Why I Ceased Being a Revolutionary', written by the renegade Populist, Lev Tikhomirov, who had forsaken his comrades and the movement to become a conservative (Figner at this time was engaged in writing an introduction to Tikhomirov's memoirs), explaining his apostasy. Furthermore, it was noted, the memoirs tended to concentrate on the experience of prison and exile rather than on revolutionary events.

${ }^{28}$ Hilde Hoogenboom, 'Vera Figner and Revolutionary Autobiographies: The Influence of Gender on Genre', in Rosalind Marsh, Women in Russia and Ukraine, Cambridge, 1996, pp. 78-93 (pp. 82-83). 
Another compilation of revolutionary life stories put together at roughly the same time was the never completed (for political reasons) multivolume bio-bibliographical dictionary entitled Figures of the Revolutionary Movement in Russia: From the Predecessors of the Decembrists to the Collapse of Tsarism (1927-33). An entire volume in this project was devoted to the revolutionaries of the 1870 ; for this volume the compilers utilized archives and published sources as well as interviews with surviving participants, and then turned to members of the OPK to review the finished manuscript. As for their memoirs, largely published around the turn of the century, the editors of the series note in the foreword to that volume that they had been valuable primarily in describing the personalities of the memoirists themselves, less so in terms of clarifying events or describing the rank-andfile members of the movement, which in any case, they added, might not be recalled with any accuracy: 'Thirty to fifty years are a long enough interval to cause memoirists to err in the precise dating of events.' The authors of the foreword also disputed the pessimistic appraisal that memoirists had given to the outcome of their efforts: 'in the light of the present [i.e., the establishment of Soviet power], the movement of that time was by no means as fruitless as the propagandists of the era themselves judged it to be. ${ }^{29}$ This was a mild version of the criticism that Populist efforts to memorialize the past were later to encounter.

\section{'I confronted the emptiness of my situation'}

We can discern several specific reasons this generation as a whole turned to the writing of memoirs, to biography and autobiography, including: to share their experience at revolutionary struggle with future generations; to compensate for their long isolation from society while in exile by leaving behind a 'trace' in the memories of their descendants, and to demonstrate the significance of their own contribution to the country's liberation movement. For those who survived imprisonment and exile, the memories remained vivid and central to their being, often shaping the rest of their lives. Thus, after experiencing more than twenty years of solitary confinement in Shlisselburg, Vera Figner wrote: 'You can't erase twenty years of your own life, years in which you experienced more than during all the rest of your life; for me the years in Shlisselburg are always with me, I won't reject them, I don't want to, nor am I able to shake them off.' ${ }^{30}$

${ }^{29}$ F. Kon, A. Shilov, B. Koz'min, V. Nevskii (eds), Deiateli revolutsionnogo dvizheniia $v$ Rossii. Bio-bibliographicheskii slovar': Ot predshestvennikov dekabristov do padeniia tsarizma, Moscow, 1929, vol. 2, part 1, p. xi.

30 Figner to Novorusskii, 19/6 November 1912. Clarens in Vera Figner, Sobranie 
Psychologically, memoir writing was also an individual tool to overcome the traumatic experience of prison and hard labour as well as to facilitate the adaptation to life under difficult new conditions. Even in the late tsarist era, after being released, former revolutionaries had trouble orienting themselves in life; perhaps the only way to do so was to put down one's experiences on paper. In search of new meaning in life, and given the impossibility of renewing their societal activities where they had left off, a commitment to this endeavour provided an exit from political and societal isolation. This was true in the aftermath of the 1905 revolution, but even more so after the far more cataclysmic events of 1917-21. Figner described her own path in this way: 'In 1913 I confronted the emptiness of my situation: there were no revolutionary tasks I could apply myself to, indeed nothing that could serve the common cause. So instead I turned to a task my friends had long urged upon me and about which I had myself been thinking for some time. I began to write. ${ }^{31}$

To be sure, her correspondence suggests she had actually started writing earlier, given lectures on the conditions experienced by political prisoners, written articles, all of this with such frequency that she finally had to make a conscious choice whether to concentrate on her memoirs alone or continue to give lectures. In a letter to Sophia Kropotkina (July 1909), Figner had described her decision to focus on her memoirs alone as an obligation to society:

In August I arrived in Switzerland and since then have started working on my memoirs. If I can proceed with the kind of energy that I occasionally experience I should be able to finish a book 5 or 6 printer's lists in length. If I can do so then I will be fulfilling an obligation I have felt ever since the moment I was released [from incarceration] and at the same time satisfying a deeply felt personal need [ $i$ vysshim udovletvorenim moego vnutrennego $i a]^{32}$

Her accounts of the writing process are very purposeful and goaloriented. At the same time, the reader will note her repeated attempts to begin with her memoirs. In one case she is too busy, but feels a moral obligation. In the second and later statement she is confronting a spiritual void. All of this is indicative of a post-traumatic experience

\footnotetext{
sochinenii, 7 vols, Moscow, 1933, 7, p. 197.

${ }^{31}$ Vera Figner, Zapechatlennyi trud, 2 vols, Moscow, 1964, 1, p. 42.

${ }^{32}$ Figner to Kropotkina, July 1909. Vera Figner, Polnoe sobranie sochinenii, 6 vols, Moscow, 1930, vol. 6, p. 510.
} 
and of a loss of meaning in life after a decade of concerted and collective revolutionary activity followed by two decades of solitary confinement, which she survived only because of the determination and resolve of her revolutionary convictions. Indeed, if one reads closely the memoirs themselves, what leaps out is just how fractured and fragile had been her orientation and sense of self upon initially returning to society, and how arduous was the process of restoring sustained contact with humanity, never mind society, itself in turmoil in 1905. Thus, we can recognize her turn to writing memoirs as proceeding in stages, as part and parcel of overcoming isolation and recovering a search for purposefulness in life. ${ }^{33}$

In different combinations we find the same mix of psychological and societal episodes in the path taken by Populists of the seventies generation to writing their memoirs. The majority of Populists rejected the October Revolution, viewing it as a political coup d'état rather than a social revolution. Echoing Charushin's own response to events, Egor Lazarev lamented:

Fifty-five years of struggle for political freedom! I sat in solitary confinement for 5-6 years, and on three occasions was subjected to administrative [rather than judicial] exile in Siberia. Oh how many years spent abroad, in emigration and in flight. Finally - an end to autocracy! Russia undergoes the greatest of revolutions and in March 1917 the ossified tsarist order is overthrown! Yet what kind of absurdity do we see then, when thousands of socialists, having paid for their free-thinking with years of confinement and hard labour, are now once again scattered over the endless tundra of Siberia and exile only to experience conditions immeasurably harsher than under tsarism. ${ }^{34}$

For Lazarev and other former Populists, a growing disillusionment with the outcome of this decades-long revolutionary struggle, as well as a perception of individual and collective superfluity in the new political environment combined to cause them to reflect upon earlier times, which they now often described as 'that distant past' (indeed, several of their

${ }^{33}$ Despite all of these hardships, Figner did in fact recover a capacity not only to write, but also to enjoy life; she took pleasure in her travels in Europe, visits to museums, and recorded joyous impressions of Europe's cultural heritage and beautiful landscapes. The depiction of Figner's psychological devastation and deep desperation during and after exile, while certainly identifying one strand in her life, makes for a monochromatic portrait.

${ }^{34}$ Columbia University, Rare Book and Manuscript Library, Bakhmeteff Archive, The Sergei Mikhailovich Kravchinskii Papers, Box 1. 
memoirs, as well as Charushin's, included in the title a variant of that phrase). Here one can also detect a strong note of nostalgia for a past which had swallowed up their youth, consumed their energies and given them hope for the future. And let us not forget that this ageing generation was literally dying out; few remained on earth to defend its legacy, and those who did felt a moral obligation to preserve the memory of those who had fallen by the wayside.

Finally, as time passed, Populists sought to ward off 'erasure' brought on not only by the passage of time, but increasingly by a hostile environment. The endeavours by Populists to leave behind their recollections at first fit well with the needs of the new Soviet state, but over time increasingly diverged from them. Vera Figner played a key role in convincing Charushin, among others, to join together in a collective effort to defend the Populist legacy against a mounting threat. In 1921 Figner had encountered what was for her an entirely unexpected and shocking challenge to her sense of place in history - to her identity. In a letter to a colleague she described what had happened:

Yesterday I was at the Petrovsko-Razumovskaia [Academy] at the invitation of students who sent along fifteen or twenty queries in advance. But it was late and I didn't get around to reading them; and I knew there would be some unwelcome questions which I had no wish to address. I had already had the occasion to respond to the likes of 'what is your stance towards the current political order?' or 'why don't you belong to the party in power today?. But I certainly didn't anticipate what I read in one of the notes I perused after returning home from my presentation; concerning the historical significance of the People's Will it read: 'your efforts were all in vain, your energies were expended heedlessly and produced no results. ${ }^{35}$

\section{'I urge you to write down your recollections'}

It was at this point that memoir writing and autobiographical essay merged with collective autobiography, especially through the process of 'travelling narratives'. In order to combat the notion that their lives had been spent in vain and fruitlessly, the seventies generation set about determinedly to create a 'collective remembrance' supporting another's efforts, verifying the accuracy and veracity of their judgements, and analysing each other's testimonies. They felt it incumbent upon themselves to preserve the

35 Figner to Novorusskii, 23 October 1921. RGALI, f. 1185, op. 1, d. 239, 1. 185. Emphasis added. 
historical memory of the times they had lived and to recount the lives of their fallen comrades, a task made all the more pressing in that so few witnesses of the era were still alive.

In 1922, Vera Figner convinced Charushin to register with the OPK. By the middle of the decade he had been drawn into the collective efforts of members of that society to defend the legacy of Populism against increasingly shrill attacks mounted by young Bolsheviks and historians. But the process was gradual and his reluctance evident. Early in January, 1924 Figner wrote in a note to Charushin:

I urge you to write down your recollections about the origins, activities and organizations of the Chaikovtsy in several cities. Such a history of the circle, remarkable in all ways, is lacking, and you must write down what you know, what you did and what you learned from others. ${ }^{36}$

Note here and below the oft-repeated accent in the correspondence of the old revolutionaries on the need to give as full and reliable a version of the activities of the Chaikovskii Circle as possible ('what you know...') The claim to authenticity would be legitimized by the fact of direct participation in the affairs of the circle itself. In reply, Charushin pointed out that:

I've been waiting all along for one of the better informed members of my circle to fulfil this task, but up to now have been disappointed in that expectation. Yours is not the first time I have heard such a request, but I confess that with all the unremitting cares of daily life, when matters of the present can swallow up one's attention, there has simply been no time to think about the past. Now however, with almost none of the Chaikovtsy still alive, the feeling is much more acute that I am obliged to the best of my abilities to fill the gaps in that area. ${ }^{37}$

But he was slow to move, and two weeks later, on 29 January 1924, Figner again urged Charushin to take up writing his memoirs, describing the act as a moral debt to those who were no longer among the living; otherwise much would be forgotten, and then irretrievably lost. She wrote:

So, for all these reasons you must get down to business, and please, no more delays. Otherwise, what if you are taken ill and won't be able to recall the details; after all this is a debt owed to the public by those of us who

${ }^{36}$ RGALI, f. 1642, op. 1, d. 77, l. 1. Emphasis added.

37 RGALI, f. 1185, op. 1, d. 817, 1. 5. 
have outlived our comrades. I am so happy I have already made my own contribution - if I had to start today and write the way I did then - I just couldn't do it. ${ }^{38}$

Figner was not alone in entreating Charushin; fellow member of the Chaikovskii Circle and lifelong friend of Charushin, Aleksandra KornilovaMoroz added her own voice to the choir:

All of us, the last among the living, have the obligation to finally clarify in a truthful and comprehensive way the many activities of that circle which made such a profound and vivid imprint upon the memories of contemporaries, set it apart from all others and put it at the forefront of the movement. ${ }^{39}$

In their letters to Charushin we again see the emphasis upon a debt to one's departed comrades of the Chaikovskii Circle as well as the striving to fix in the memory of generations to come the prominent role that that circle had played in the history of the revolutionary movement as a whole. This idea had arisen much earlier, during their collective imprisonment awaiting trial in the middle of the 1870s, and again after release at the turn of the century, but now was posed with far more urgency. ${ }^{40}$

Later, in December 1924, Kornilova-Moroz (who was herself writing a biography of Sofia Perovskaia, the legendary terrorist and member of the Chaikovskii Circle), prepared to send Charushin the memoirs of Leonid Shishko for use in his own account of events. She added a note: had he actually begun writing yet? Once more, in February 1925 she wrote to let him know that Vera Figner had confirmed the accuracy of his own replies to queries she, Kornilova-Moroz had made for her book concerning the early activities of their circle, as well as his commentary on Shishko's memoirs. Hence they were all on the same page on such matters - all the more reason for him to finally begin.

It seems that at this time Charushin was genuinely turning to the task of writing, for he sent Kornilova-Moroz a letter with a list of queries about the political stances of members of the circle, the details of the programme of the Chaikovtsy and their understanding of the practical tasks confronting them. But she was taking no chances. He received a detailed response from her in which she passionately reminded him once again of the importance

${ }^{38}$ RGALI, f. 1642, op. 1, d. 77, 1. 30 b.

39 RGALI, f. 1642, op. 1, d. 51, l. 1.

${ }^{40}$ Gosudastvennyi Arkhiv Rossiiskoi Federatsii (hereafter, GARF). f. 112, op. 2, d. 2468. 
of contributing his remembrances: 'Your recollections are extremely valuable [...] please get down to this soon. ${ }^{41}$

When he finally set about the task of writing its memoirs, it was not only because of the persistent entreaties of Vera Figner, who enjoyed enormous authority among the older revolutionaries, or of a lifelong fellow member of the Chaikovskii Circle and family friend, Kornilova-Moroz, or even his own sense of moral obligation to his generation. Also weighing in to convince him to write about his past were the core of old revolutionaries in the OPK. Evidence of this can be found in a later letter Charushin sent after the fact in 1927 to one of its members, Maria Shebalina: 'Please give my warmest greetings [...] to the circle, whose assignment I received last summer and now have carried out, for better or worse'. ${ }^{42}$ In short, when Charushin set about the task of putting in words his recollections it was only after prolonged procrastination and despite deep reservations, at the urging of his friends and insistence on their importance as a collective project of reconstruction and authentication.

\section{The Writing of 'Remembrances'}

Perhaps Charushin's lengthy hesitation also stemmed from his awareness of the perils of relying upon individual recollection alone. Writing in 1926 he commented upon the doubts that had beset him when he first took up this project:

Over the years the memories had faded, much had been entirely lost. Most importantly, I was apprehensive that my efforts to reproduce and evaluate the events of the past would be involuntarily coloured by the atmosphere of subsequent times and that the result would convey a distorted picture of what I was describing. ${ }^{43}$

From the start, in order to avoid that from happening, Charushin's memoirs were written with a keen eye to the accounts of other members of the Chaikovskii Circle; citing these accounts, and utilizing a voluminous correspondence with these others in the movement. Earlier, as his correspondence shows, he had paid close attention to the memoirs written by his peers: in 1906 he had written to his wife Kuvshinskaia, who had been exiled to Perm', describing his excitement at reading for the first

${ }^{41}$ RGALI, f. 1642, op. 1, d. 51, 1. 12 ob.

$4^{2}$ Charushin to Shebalina, 3 March 1927, Viatka. Tsentral'nyi Istoricheskii Arkhiv Moskvy (hereafter, TsIAM), f. 2241, op. 1, d. 138, 1. 1a. Emphasis added.

${ }^{43}$ Nikolai Charushin, O dalekom proshlom, Moscow, 1973, p. 17. 
time the memoirs of Sinegub and Shishko: 'The mail has arrived, bringing new issues of Byloe and Russkoe Bogatstvo and I was absorbed reading [...] about those "old" times. ${ }^{44}$ Those two journals with a Populist orientation had begun publishing memoirs of the seventies generation, many of whom had only recently been released from exile. Charushin discussed these memoirs with Kuvshinskaia, encouraging her to write down her own remembrances, since he felt that those of their good friend Sinegub were incomplete and excessively subjective. Even more, they were 'simplistic and imprecise to the degree that he even makes me out to be a died-in-the wool anarchist. ${ }^{45}$ In contrast, later, when contemplating writing his own memoirs, Charushin read carefully those of Ivan Popov, and confessed to the latter that in doing so: 'I was pleased and even surprised at how luminous were your recollections of that relatively distant past - so much so that I am now intimidated at the thought of launching such a project. ${ }^{36}$

Once he did start writing he discussed his recollections regularly with Kornilova-Moroz. In April, 1926 she wrote to him:

If you find it more opportune to meet with me in Moscow to go over your memoirs, I will be able to travel there in May. There I hope we will be able to get permission to work in Petr Alekseevich's [Kropotkin's] room in the museum [of that name], where nobody will disturb us, since the museum is open only two days a week. ${ }^{47}$

Moreover, in the introduction to his memoirs Charushin underscores the fact that Kornilova-Moroz had given her seal of approval to the manuscript as a whole. In his view this served as testimony to the veracity and authenticity of his account. Once $O$ dalekom proshlom had been published Charushin welcomed the proposal made by members of the OPK that it was she and nobody else who should write a review for the organization's own journal, Katorga i Ssylka. In his view, she would be best, for as a veteran of the Chaikovskii Circle she could testify that 'what I had written did not

${ }^{44}$ Charushin to Kuvshinskaia, 3 November 1906. RGALI, f. 1642, d. 108, 1. 11 ob.-12.

${ }^{45}$ Charushin to Kuvshinskaia, 17 November 1906. RGALI, f. 1642, d. 108, 1. 16 ob. The assertion that Charushin had anarchist leanings in earlier years was one he vehemently denied. It should be added that despite this criticism, Charushin had tried to convince his acquaintance, the noted Moscow bookman and sponsor of Charushin's newspaper, Aleksandr Charushnikov, to publish Sinegub's memoirs as a book, in order to help out his friend 'Silych' (as he affectionately called him) financially. Charushin to Kuvshinskaia, 10 February 1907. RGALI, f. 1642, d. 108, 1. 41 ob.

${ }^{46}$ Charushin to Popov, 24 April 1924. RGALI, f. 408, op. 1, d. 114, l. 1.

47 RGALI, f. 1642, op. 1, d. 51, 1. 18 ob. 
doctor up the facts or include any outright inventions... When she does write the review, she can also make up for any omissions on my part'. ${ }^{48}$

In addition, in 1926, after the first volume of $O$ dalekom proshlom had been published and, at the urging of the editors of Katorga i Ssylka, a circle of 'elders' at the OPK was established (it was this group whose 'assignment' Charushin above mentioned having completed). As Kornilova-Moroz wrote: 'they met weekly, during which one of them would relate his own life story, which was then taken down by a stenographer, and later turned into an article for the journal. ${ }^{49}$ Charushin continued to work on his own memoirs, now focusing on the period of exile, and in so doing continued to turn to his peers in this group to verify dates and to clarify the historical context.

In his third and final volume, covering the period of resettlement in the region of the notorious Nerchinsk gold mines, and later in Kiakhta on the border with China, Charushin continued to rely upon others to clarify and validate his own description of people, sites and events. For example, when engaged in writing about the visit of the Stakhevich family (Vera Figner's sister Lydia was married to Sergei Stakhevich) to Troitskosavsk in 1894-95, Charushin wrote to their daughter Tatiana Stakhevich to clarify a misunderstanding about that date. Another connected figure, Mikhail Sazhin (married to Vera Figner's sister Evgeniia), had insisted that the Stakhevich family had actually been there at an earlier point; in response Stakhevich's daughter sent him an exhaustive description of the visit drawn from her family's archive..$^{50}$ In the volume itself, Charushin refrains from a detailed description of the colourful and diverse tea entrepôt Kiakhta, noting that he deferred to the memoirs of Popov, which had done just that. Throughout this interval he was also re-reading 'with enormous pleasure' the five volumes of Figner's memoirs, something he noted to Popov himself in December 1929. ${ }^{51}$

It was not always smooth going, and however important achieving factual accuracy was for the group, other conditions also sometimes weighed in, for leaving behind the legacy of a group which had always observed a high standard of ethics was also crucial. For example, after reading Mikhail Chernavskii's Kara memoirs, which he found highly interesting and well written, Charushin noted that they had also helped

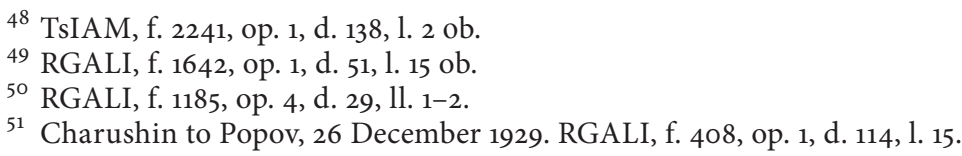


him substantially in his description of the ignominious Uspenskii episode, which he himself was grappling with in his own volume, $\mathrm{Na}$ Kare.

In this episode, Petr Uspenskii, a member of Nechaev's organization, had been sent to the Kara mines in 1875, where he intermingled with Chaikovtsy until 1881. In that year he was transferred to the prison in the Lower Kara region along with others who had been consigned to hard labour. There, because he was suspected of betraying his comrades, who had been digging an escape tunnel, he was murdered. In his memoirs Charushin depicts Uspenskii's psychological condition, his conflict with other prisoners, and searches to explain what led his comrades to falsely suspect Uspenskii of treason, something which led to that tragic outcome. At the time this had happened, Charushin was no longer imprisoned or in the locality, so he had of necessity relied heavily upon Chernavskii's account, citing his contribution to Katorga i Ssylka. ${ }^{52}$

At the same time, long before that he had known of Uspenskii's innocence, having been told crucial information shortly after the event by the Kara camp commandant Kononovich, with whom he had a cordial relationship. In a letter to Shebalina written in 1927, Charushin confided:

I had the distinct impression that the suspicion of Uspenskii originated in the collapse of the first tunnel and that Kononovich had learned about it quite accidentally from somebody close to the prison who had had no intention of divulging the fact. Anna Dmitrievna [Kuvshinskaia] and I heard this directly from Kononovich when we were living in Nerchinsk. Unfortunately, I still can't make that fact public; all I can do is, based upon what I do know, categorically deny that Uspenskii had anything to do with the matter - whether directly or indirectly. Even with that knowledge, however, I would prefer to address a number of questions to Mikhail Mikhailovich [Chernavskii] about the matter. ${ }^{53}$

It was doubly uncomfortable for Charushin to write about this episode because, on the one hand he could not believe that Uspenskii was a traitor, given that he of all people was the least likely to have had any contact with Kononovich. In fact Charushin believed that the accusations had been inept and shameful. Yet on the other hand, the wrongful execution of Uspenskii cast the community of political prisoners in an odious light. All he could do by means of exoneration was to emphasize how the prison experience

${ }^{52}$ Mikhail Chernavskii, 'Ippolit Nikitich Myshkin (Po vospominaniiam katorzhanina 70-80-kh g.g.)', Katorga i Ssylka, 7-8 (28-29), 1926, pp. 104-24.

53 TsIAM, f. 2241, op. 1, d. 138, 1. 1a. 
shaped people, creating unfounded suspicions of one another, with tragic outcomes of this sort. For Charushin this had certainly been a catastrophe, since it seemed to imply that the Chaikovtsy were not above the amoral methods of Nechaev - rejection of which had been the alpha and omega of their own group and was at the centre of their generational identity.

We note in this story Charushin's determination not to distort the facts or err in the depiction of events, but also see the moral constraints framing his recollections of those of his comrades who were no longer among the living, or even those still with him. It was no accident that Charushin was circumspect in describing Kononovich's revelations even in his private correspondence. It might well also be the case that Kononovich had actually shared with him the name of the person who had inadvertently spilled the news about the tunnel and escape plans of the prisoners, and that Charushin had no wish to expose that unfortunate person.

Others in the group shared the concern not to wash their dirty linen in public. In a letter to Vera Figner, Aleksandra Kornilova-Moroz vented her anger against Mikhail Sazhin for wanting to include in his memoirs examples of the interpersonal discord in their earlier years. As she put it, writing his memoirs was all well and good:

But it is repulsive that Sazhin wants to bring up all the garbage [...]. Instead of giving our young people something uplifting to bolster their downtrodden spirits, here you are: he and Svetlovskii beat up an ailing Smirnov; an aggrieved Zavadskaia slaps [illegible] in the cheek, who in turn rips up her clothing and pulls a revolver on her; it's only due to the actions of Zavadskaia's companion Frits, who knocks the gun out of [that person's] hand that a murder is avoided. What a great scene, how worthy of our intelligentsia and right-thinking [ideinye] people!! Mucking around in the garbage heap! It's bad enough that it actually happened in the past; bringing it all up again is really awkward [...]. And he wants to commemorate these inspiring episodes!!! ${ }^{54}$

The Uspenskii and Sazhin incidents serve as a useful reminder that interpersonal relations were not always stable and the actions of these revolutionaries sometimes felt short of their ethical ideals - whether it concerned private or public matters. Indeed, in their efforts to create a collective biography of their generation they were not averse to leaving out such episodes. Nevertheless, a close reading of their abundant

54 Aleksandra Kornilova-Moroz to Vera Figner, 31 August n/d. RGALI, f. 1185, op. 1, d. 6o2, 11. 66-66 ob. 
correspondence also tells us that these were the exception rather than the rule - their close friendships and aspirations to live lives governed by high moral standards prevailed.

\section{Travelling (Entangled) Narratives}

Turning frequently to the memoirs and biographies of other revolutionaries, and consulting over and over again by mail or in person led ineluctably to something resembling a 'collective' remembrance. On occasion one or another former Chaikovets might even directly borrow a passage from the works of another without acknowledging its origins, simply merging the words written by another into one's own text - something only a close word-by-word analysis of these memoirs has revealed. For instance, Kornilova-Moroz borrowed freely from the memoirs of Kropotkin and Figner. She made it clear that doing so was part of the normal creative process of writing. She wrote:

Thanks to books I obtained from the library [...] I was able to insert into my own account some really interesting passages, such as the one of the colourful scene from the Trial of the 193 when [Hyppolite] Myshkin finished his speech and the gendarmes dragged him by force out of the courtroom. [Vasily] Bogucharskii himself borrowed this from the newspaper Obshchina published in Geneva in 1877-78. I also took the obituaries of [Anatoly] Serdiukov and [Mikhail] Kupreianov from Lavrov, which I found there. As for the depiction of the Chaikovskii Circle, I borrowed that from Kropotkin, and pulled a couple of passages from [Figner's] The Imprint of Life's Endeavours. ${ }^{55}$

On such example of the kind of 'travelling narrative' that such endeavours produced in $O$ dalekom proshlom is the description of Kara, the notorious prison and hard-labour site in Siberia. In his description of his stay at Kara, Charushin made use of both Shishko's and Sinegub's own memoirs. As he put it in the foreword to his second volume published in 1929: 'Life at Kara at that time has already been described in part by Sinegub and, less so, Shishko; for that reason there is some inevitable repetition in my own narration, something unavoidable if I wanted to give a full picture of what life was like there. 56

Before 1882, the prisons at Kara were the only place to which those convicted of crimes against the state were sent. Stories circulated of gross

55 RGALI, f. 1642, op. 1, d. 51, 11. 14-14 ob.

${ }^{56}$ Charushin, Na Kare, Moscow, 1929, p. 8. 
and arbitrary treatment there by the authorities, of the lack of rights, the desolate taiga, which provided no opportunity for flight. At the same time, according to a former prisoner, Naum Gekker, 'being sent to Kara was considered a great privilege, for it was regarded as a site of freedom, even a republic, and for that reason was in bad repute among the higher authorities. ${ }^{57}$ Judging by the memoirs of Sinegub and Charushin, life at Kara was not difficult for them, and in contrast to later recollections, the Chaikovtsy were free to dispose of their time, to study foreign languages and crafts, and read widely and interact freely, more of a club than penal servitude. Recalling his stay at Kara almost fifty years earlier, Charushin admitted that after almost four years of solitary confinement in the PeterPaul fortress and elsewhere, Kara was almost like a resort, providing for the restoration of one's physical and mental capacities.

Such descriptions of the tsarist penal system, published in the 1920s, ran contrary to the prevailing narrative. At this very time Katorga i Ssylka was frequently printing the accounts of other former political prisoners, depicting cruel conditions, suffering and abuse. These other accounts came largely from those who arrived at Kara later, during the $188 \mathrm{os}$, when there was a vast expansion in numbers, a specially built prison and new rules. But even among these later prisoners there were many whose account of their time at Kara fit poorly with the general narrative of suffering. They recalled their life together at Kara in warm language, as a period rich and complex in its social interaction, one observing an unwritten constitution, rules and customs, an important source of education and socialization. 'An entire generation of revolutionary youth passed through the Kara political prison, and for scores of young people just coming into maturity it was a welcoming alma mater, a university and a public arena. ${ }^{58}$ Why, then, this type of narrative, despite the undoubted instances of violence on the part of the authorities, protests by prisoners extending even to hunger strikes and suicide, as well as internal conflicts? First of all, conditions were truly better than those prevailing in Shlisselburg or the Peter-Paul Fortress. Second, the period of incarceration came during the 'best years of their lives' (as they wrote), when youth, close friendships in the revolutionary movement, and belief in a bright future provided the strength to endure the hardships of imprisonment. Many explained the existence of a society of equals, a prison 'parliament' and 'constitution' by the high level of consciousness, the intellectual and moral qualities setting the revolutionaries apart from the world outside. Because of these qualities

57 Naum Gekker, 'Politicheskaia katorga na Kare (vospominaniia)', Byloe, 1906, 9, p. 71. ${ }^{58}$ Ibid. 
they were able to create an almost ideal community and full equality, that which they had failed at doing earlier because of, so they believed, the low level of development of the peasantry. The 'Kara Republic', as they called it, could serve as a social experiment of sorts, displaying both the successes and difficulties of building a new society.

The search for a common narrative when it came to the Kara experience often led the memoirists to a striking correspondence in phrasing. One example can be found in the depictions of the camp commandant, Kononovich, who treated the prisoners with respect and did everything in his power to ameliorate their conditions. Sinegub describes Kononovich as follows: 'He was a man not yet old, well built, with a wise, intelligent face, dressed in a military uniform. ${ }^{59}$ In Charushin's account, we read: 'This was a tall man, around 40-50, with a military demeanour, a wise and intelligent face, dressed military style. ${ }^{60}$ Again, Sinegub: 'Kononovich was both a smart and intelligent man, well able to defend his turf as long as it was even possible. ${ }^{61}$ And, Charushin: 'Kononovich was a smart man, no coward, and able to defend his turf.' ${ }^{62}$

In order to add weight to the veracity of his portrait of Kononovich, Charushin refers to George Kennan's famous book on the exile system, ${ }^{63}$ translated into Russian in 1906, well known there, and often cited in other memoirs. ${ }^{64}$ For all practical purposes, Kennan's text became a part of historical memory and a means of legitimating the revolutionaries' recollections about their experience of exile, but was also inseparably interwoven with their own collective narrative. Charushin introduces a lengthy quotation from Kennan, in which he writes: 'Political prisoners, local bureaucrats, and decent people in general, always spoke to me in one voice, that this was a humane, attractive, courageous, intelligent and complete incorruptible civil servant. ${ }^{65}$ Strikingly, Kennan himself, referring to the views of the political prisoners as a whole, directly cited the opinions of Charushin, whom he had met while in Siberia, on the topic. ${ }^{66}$ As a result, on more than one occasion, in the descriptions of

59 Sergei Sinegub, Zapiski chaikovtsa, Moscow, 1929, p. 253.

${ }^{60}$ Charushin, Na Kare, pp. 18-19.

${ }^{61}$ Sinegub, Zapiski chaikovtsa, p. 256.

${ }^{62}$ Charushin, Na Kare, p. 38.

${ }^{63}$ George Kennan, Siberia and the Exile System, vols 1 \& 2, New York, 1970, 2, pp. 206-10; 216-20. The volumes were first published in 1891 .

${ }^{64}$ For the history of the translation and publication of this work, see E. I. Melamed, Dzhordzh Kenan protiv tsarizma, Moscow, 1981, pp. 60-72.

${ }^{65}$ Charushin, Na Kare, p. 102.

${ }^{66}$ Kennan, Siberia and the Exile System, 2, pp. 118, 209, 210, 216, 324, 325, 450. 
Kononovich in the memoirs of Sinegub, Charushin, Kennan, and later, the monumental history of tsarist prisons by Gernet, we find a word-for-word correspondence. ${ }^{67}$ They all quote each other - a hall of mirrors of sorts.

This gives rise to the thorny question of who in fact originated the description which, repeated over and over again, turned into a 'travelling' or 'entangled' narrative. At times it was a conscious endeavour; at others, as Figner wryly pointed out, their connection was so close that this occurred unintentionally even when they were writing largely in isolation from one another. After reading Mikhail Novorusskii's remembrances of their time at Shlisselburg Vera Figner wrote to him:

Despite all the differences in tone and construction [...] I found so much agreement on so many occasions, and to such a degree that you might even think we copied from one another - which given the time of writing could not have been the case. I got a good laugh reading the first part of your foreword: the draft of my own foreword, written while I was in Lugan' [in Orel province] is virtually the same, word-for-word! In general your book and mine will complement each other. ${ }^{68}$

Thus we find considerable evidence of the 'intertextuality' - to use the term freely - of Populist memoirs. ${ }^{69}$ The former Chaikovtsy sought to speak in unison. The process of constructing memoirs involved relying upon individual memory, turning to the already formulated recollections of other participants in the revolutionary movement, and discussion when possible of key moments, all of which in the end led to the creation of a 'collective autobiography'. At the same time the commonality of views, the collective experience and even - one might say - identity, also led on its own to the construction of almost identical narratives.

${ }^{67}$ Mikhail Gernet, Istoriia tsarskoi tiur'my, 5 vols, Moscow, 196o, 3, pp. 317-18, 320-21. Gernet calls him Kananovich.

68 Figner to Novorusskii, 17 May 1920. RGALI, f. 1185, op. 1, d. 239, 1. 145. Emphasis added.

${ }^{69}$ It was common practice for these former revolutionaries to utilize other memoirs, biographies, histories of the movement in their own autobiographical writings. The result was a 'collective remembrance' in which passages pulled from elsewhere were inserted into the new text without what we would call the proper attribution. Only a line by line comparison of memoirs made it possible to identify this practice among the Populist memoirists. 


\section{Conclusions}

In sum, the memoirs of Nikolai Charushin, as well as of Sergei Sinegub, Aleksandra Kornilova-Moroz, Leonid Shishko, Ivan Popov, Sergei Kovalik and others can be viewed as an element of generational memory. As Lazarev wrote: 'We are linked inseparably by the irretrievable past. ${ }^{.70}$ As Assmann pointed out, of all the variants of social memory, generational memory is the most stable, and indeed the seventies generation of Chaikovtsy retained their identity through thick and thin until the end of their lives.

It was of course nothing out of the ordinary for these former revolutionaries, when sitting down to write their memoirs, to turn to one another to corroborate facts and compare notes. Yet we believe that something else was afoot here; the determination to speak in one voice was a political statement but not only. It was also a collective effort at life writing as an attempt to fix the image of their generational cohort, along with its ideals and activities, in historical memory. Because of this, Charushin's' contemporary, Shmuel Levin, was surely right when he observed, in his review of $O$ dalekom proshlom:

Charushin put his pen to paper later than all his other comrades and contemporaries and had their accounts in front of him when writing, as well as much only recently published materials from the archives. For this reason his account can be viewed as a dialogue with, but also summation of, all others. ${ }^{71}$

In her book on the legacy of the Decembrist movement, Ludmilla A. Trigos astutely emphasizes the strivings of the Decembrists themselves to mythologize their own history; she depicts the later reshaping and mobilization of this mythology in order to establish a genealogy of the revolutionary movement in the Soviet era. ${ }^{72}$ As we have seen, the portrait of the seventies generation was likewise actualized in the Soviet Russia of the 1920 s in the context of the effort to create and instil a new values orientation, to raise the younger generation with a diet of heroic images of the past, to establish a pantheon of heroes and sites of memory.

But the catcalls Vera Figner had heard earlier in the decade ('your efforts were all in vain, your energies were expended heedlessly and produced no

70 Columbia University, Rare Book and Manuscript Library, Bakhmeteff Archive, Sergei Mikhailovich Kravchinskii Papers, Box 1.

${ }_{71}$ Levin Sh., 'N. A. Charushin. O dalekom proshlom', Istorik-Marksist, 1927, 4, p. 242. Emphasis added.

${ }^{72}$ Ludmilla A. Trigos, The Decembrist Myth in Russian Culture, New York, 2009. See, especially, chapter 2 . 
results') now threatened to drown out the voice of the Populists entirely. The social memory of that cohort contradicted the new and official political memory under construction at the time; it was destined to be altered or entirely obliterated without become a trans-generational memory. As Trigos shows, discussion of the Decembrist myth temporarily faded in the decade after the 1925 centennial just as the struggle over the legacy of Populism intensified. By the 1930s, during the Cultural Revolution and with the rise of the Stalinist cult of personality, Populist heroes, and therefore the seventies generation, were no longer needed by the authorities and relegated to the dustbin of history. The stream of memoirs dried up and representatives of this generation, bearers of this collective memoir, gradually left the scene. Finally, in 1935, in a fate perhaps worse than oblivion, the Populists were dressed up in history textbooks as the most treacherous enemies of Marxism. ${ }^{73}$ Under Stalinism, the 'Decembrist myth' continued to be reshaped, while the nightmare of oblivion feared by the Populists seemed to have come true.

Returning to the theoretical framework of memory studies, we have seen how generational memory shaped by the shared political experiences of the 1870 and inscribed over time by a collective autobiographical project, briefly became institutionalized as part of political memory in early Soviet Russia, and then was erased. But in the post-Stalin era it was to re-emerge as historical memory. ${ }^{74}$ The revolutionary cohort of the 1870 s had been cast out of the new triumphal historical narrative of the Stalin era, but remained an integral part of the social memory of the Russian intelligentsia. The two strands - Decembrists and Populists - were joined again in the Thaw and Perestroika eras, as the intelligentsia, including some historians, sought to recover the interwoven, but occluded connections between revolution and freedom, along with notions of personal honour and ethical behaviour that many felt had been erased in the Soviet era.

73 Nikolai Troitskii, Russkoe revoliutsionnoe narodnichestvo 187o-kh godov (Istoriia temy), Saratov, 2003, pp. 16-31.

74 See Tatiana Saburova and Ben Eklof, Druzhba, sem'ia, revoliutsiia: Nikolai Charushin i pokolenie narodnikov 1870-ikh godov v Rossii, Moscow, 2016 (chapter 10). 